\title{
MEDIA PEMBELAJARAN BERBASIS WEB PADA MATA PELAJARAN BIOLOGI KELAS X
}

\author{
Joko Kuswanto \\ Universitas Baturaja, Indonesia
}

\begin{abstract}
ABSTRAK
Penelitian ini bertujuan untuk mengembangkan media pembelajaran berbasis web pada mata pelajaran biologi kelas X. Metode penelitian yang digunakan adalah penelitian pengembangan dengan menggunakan model prosedural. Model yang dilakukan dengan tahapan prosedur pengembangan yaitu (1) Tahap perencanaan berupa analisis kebutuhan, menyusun Garis Besar Isi Media (GBIM) dan Jabaran Materi (JM), menyusun naskah (storyboard); (2) Tahap Produksi berupa persiapan, pelaksanaan, penyelesaian; (3) Tahap Evaluasi berupa evaluasi pramaster, revisi, uji lapangan. Hasil penelitian ini menunjukkan bahwa media pembelajaran berbasis web yang dikembangkan pada mata pelajaran biologi kelas $\mathrm{X}$ sudah layak untuk digunakan dalam pembelajaran di sekolah. Berdasarkan beberapa tahapan uji coba, media pembelajaran berbasis web dikategorikan valid dengan dengan kriteria baik. Penelitian pengembangan media pembelajaran berbasis web ini diharapkan dapat menjadi media pembelajaran mata pelajaran biologi serta dapat bermanfaat bagi guru, siswa, dan peneliti lanjutan.
\end{abstract}

Kata Kunci: penelitian pengembangan, media pembelajaran

\section{PENDAHULUAN}

Perkembangan ilmu pengetahuan dan teknologi saat ini telah membawa pengaruh yang besar dalam bidang pendidikan, seperti adanya televisi pendidikan, komputer, teleconfrent, dan internet. Hal ini menyebabkan pendidik harus bisa mengikuti perkembangan tersebut, karena semua pesan dan informasi dapat disajikan melalui media sesuai kebutuhan. Pengaruh perkembangan tersebut terlihat jelas dalam upaya-upaya pembaharuan sistem pendidikan dan pembelajaran serta media pembelajaran. Media pembelajaran yang dulunya hanya berupa buku atau berbasis cetak, saat ini dapat dibuat dengan menggunakan sistem berbasis web sehingga tidak hanya menampilkan teks dan gambar namun juga bisa menampilkan materi berbentuk multimedia seperti adanya video sehingga lebih menarik siswa dalam belajar. Media pembelajaran berbasis web adalah sebuah media pembelajaran yang dibuat dengan memanfaatkan teknologi web sehingga bisa diakses melalui jaringan online atau bisa juga diterapkan pada http://ojs.stkippgri-lubuklinggau.ac.id/index.php/JPP 
sebuah jaringan lokal yang dikenal dengan local area network (LAN) (Heru: 2015).

Dengan hadirnya pembelajaran berbasis web yang didesain, dikembangkan, dan dimanfaatkan sebagai media pembelajaran, memberikan ruang yang tidak terbatas bagi siswa untuk mengikuti pembelajaran. Kontribusi web pembelajaran dapat mengubah gaya belajar siswa menjadi lebih efektif dan efisien. Selain itu informasi-informasi yang dikemas dalam web pembelajaran lebih menarik, materi-materi yang dikombinasikan dengan gambar, gerak, animasi, dan suara, sehingga membuat informasi yang disajikan menjadi menarik serta menambah semangat siswa untuk mengikuti kegiatan pembelajaran.

Permasalahan yang sering dijumpai dalam dunia pendidikan saat pembelajaran dilakukan di dalam kelas khususnya mata pelajaran biologi kelas $\mathrm{X}$ adalah tentang sikap siswa yang kurang konsentrasi, sering bermain sendiri, atau bahkan melamun saat guru menyampaikan materi karena metode yang digunakan kurang variatif seperti menjelaskan materi dengan bantuan buku saja atau meminta siswa untuk mencatat materi di papan tulis. Sehingga dapat membuat siswa lebih cepat bosan karena tidak ada audio, animasi, dan gambar yang tidak disertai warna sehingga kurang menarik untuk dilihat.

Media pembelajaran yang diterapkan yaitu media berbasis cetak (buku teks) dan belum dimanfaatkan media berbasis web. Dengan media pembelajaran berbasis web dapat memadukan gambar, suara, animasi bahkan video yang dapat ditampilkan menggunakan LCD proyektor sehingga dapat menarik perhatian siswa. Hal tersebut terjadi karena anak lebih tertarik melihat animasi dan mendengarkan musik dibandingkan dengan metode konvesional yang terkesan monoton. Selain itu, metode ini berdampak positif untuk mempermudah daya ingat anak terhadap materi yang disampaikan oleh guru dan mempermudah dalam mengajari anak.

Berdasarkan uraian diatas menunjukkan bahwa perlu adanya pengembangan media pembelajaran berbasis web pada mata pelajaran biologi kelas X. Media pembelajaran tersebut dapat dijadikan media belajar bagi peserta 
didik baik disekolah maupun diluar sekolah, serta dapat digunakan oleh pendidik sebagai media pembelajaran dalam proses belajar mengajar.

Penelitian yang dilakukan bertujuan untuk mengembangkan media pembelajaran berbasis web pada mata pelajaran biologi kelas X. Penelitian ini diharapkan dapat menghasilkan produk berupa media pembelajaran berbasis web yang sesuai dengan kebutuhan siswa kelas $\mathrm{X}$ serta sesuai dengan kurikulum dan silabus yang berlaku.

\section{LANDASAN TEORI}

Menurut Tim EMS (2014:1) "Website adalah apa yang anda lihat via browser, sedangkan yang dimaksud sebagai "web" sebenarnya adalah sebuah aplikasi web, karena melakukan action tertentu dan membantu anda melakukan kegiatan tertentu. Ketika anda membuka facebook, path, twitter, atau instagram, itu adalah contoh-contoh aplikasi web”. Apapun jenisnya, website punya satu ciri, yaitu terdiri dari halaman-halaman web (web pages). Jadi, apabila website diibaratkan sebuah buku, webpages adalah halaman-halamannya.

Pembelajaran berbasis web memang menjadi populer saat ini, dimana sebuah aplikasi teknologi web digunakan dalam pembelajaran untuk sebuah proses pendidikan. Menurut Rusman (2013:311) "Pembelajaran berbasis yang populer dengan sebutan Web-Based Education (WBE) atau kadang disebut elearning (electronic learning) dapat didefinisikan sebagai aplikasi teknologi web dunia pembelajaran untuk sebuah proses pendidikan".

Menurut Rusman (2013:311) pembelejaran berbasis web "secara sederhana dapat dikatakan bahwa semua pembelajaran dilakukan dengan memanfaatkan teknologi internet dan selama proses belajar dirasakan terjadi oleh yang mengikutinya, maka kegiatan itu dapat disebut sebagai pembelajaran berbasis web". Pembelajaran dirancang dengan mengintegrasikan pembelajaran berbasis web dalam program pembelajaran. Selain itu diperlukan sebuah desain instruksional sebagai model belajar layakknya dengan kegiatan belajar di ruang kelas yang melibatkan peserta didik terlibat dalam kegiatan belajar. 
Sebagaimana media pembelajaran pada umumnya, setiap media pembelajaran tentunya memiliki kelebihan dan kekurangan seperti halnya pembelajaran berbasis web. Rusman (2013: 299) menyebutkan beberapa kelebihan pembelajaran berbasis web yaitu:

1) Memungkinkan setiap orang di manapun, kapanpun, untuk mempelajari apapun.

2) Pebelajar dapat belajar sesuai dengan karakteristik dan langkah dirinya sendiri, karena pembelajaran berbasis web membuat pembelajaran bersifat individual.

3) Kemampuan untuk membuat tautan (link), sehingga pebelajar dapat mengakses informasi dari berbagai sumber, baik di dalam maupun di luar lingkungan belajar.

4) Sangat potensial sebagai sumber belajar bagi pebelajar yang tidak memiliki cukup waktu untuk belajar.

5) Dapat mendorong pebelajar untuk lebih aktif dan mandiri di salam belajar.

6) Menyediakan sumber belajar tambahan yang dapat digunakan untuk memperkaya materi pembelajaran.

7) Menyediakan mesin pencari yang dapat digunakan untuk informasi yang mereka butuhkan.

8) Isi dari materi pembelajaran dapat di-update dengan mudah.

Disamping kelebihan tersebut terdapat beberapa kekurangan dalam pembelajaran berbasis web sebagai berikut:

1) Keberhasilan pembelajaran berbasis web bergantung pada kemandirian dan motivasi pembelajar.

2) Akses untuk mengikuti pembelajaran dengan menggunakan web seringkali menjadi masalah bagi pembelajar.

3) Pembelajar dapat cepat merasa bosan dan jenuh jika mereka tidak dapat mengakses informasi, dikarenakan tidak terdapatnya peralatan yang memadai dan bandwidth yang cukup.

4) Dibutuhkan panduan bagi pebelajar untuk mencari informasi yang relevan, karena informasi yang terdapat di dalam sangat beragam.

5) Dengan memnggunakan pembelajaran berbasis web, pebelajar terkadang merasa terisolasi, terutama jika terdapat keterbatasan dalam fasilitas komunikasi. 


\section{METODE PENELITIAN}

Metode penelitian yang digunakan adalah penelitian pengembangan. Menurut Borg \& Gall (2003: 772), penelitian pengembangan adalah penelitian yang berorientasi untuk mengembangkan dan memvalidasi produk-produk yang digunakan dalam pendidikan. Pengembangan media pembelajaran berbasis web menggunakan model prosedural (Putra: 2011) merupakan model yang bersifat deskriptif, menunjukkan langkah-langkah yang harus diikuti untuk menghasilkan produk. Model yang dilakukan dengan tahapan prosedur pengembangan yaitu (1) Tahap perencanaan berupa analisis kebutuhan, menyusun Garis Besar Isi Media (GBIM) dan Jabaran Materi (JM), menyusun naskah (storyboard); (2) Tahap Produksi berupa persiapan, pelaksanaan, penyelesaian; (3) Tahap Evaluasi berupa evaluasi pramaster, revisi, uji lapangan (Warsita, 2008: 227).

\section{HASIL DAN PEMBAHASAN}

\section{Hasil Pengembangan Produk}

Produk akhir dalam penelitian ini yaitu media pembelajaran berbasis web yang digunakan sebagai media pembelajaran. Media pembelajaran berbasis web ini terdiri dari halaman-halaman yang saling terhubung menggunakan tomboltombol.

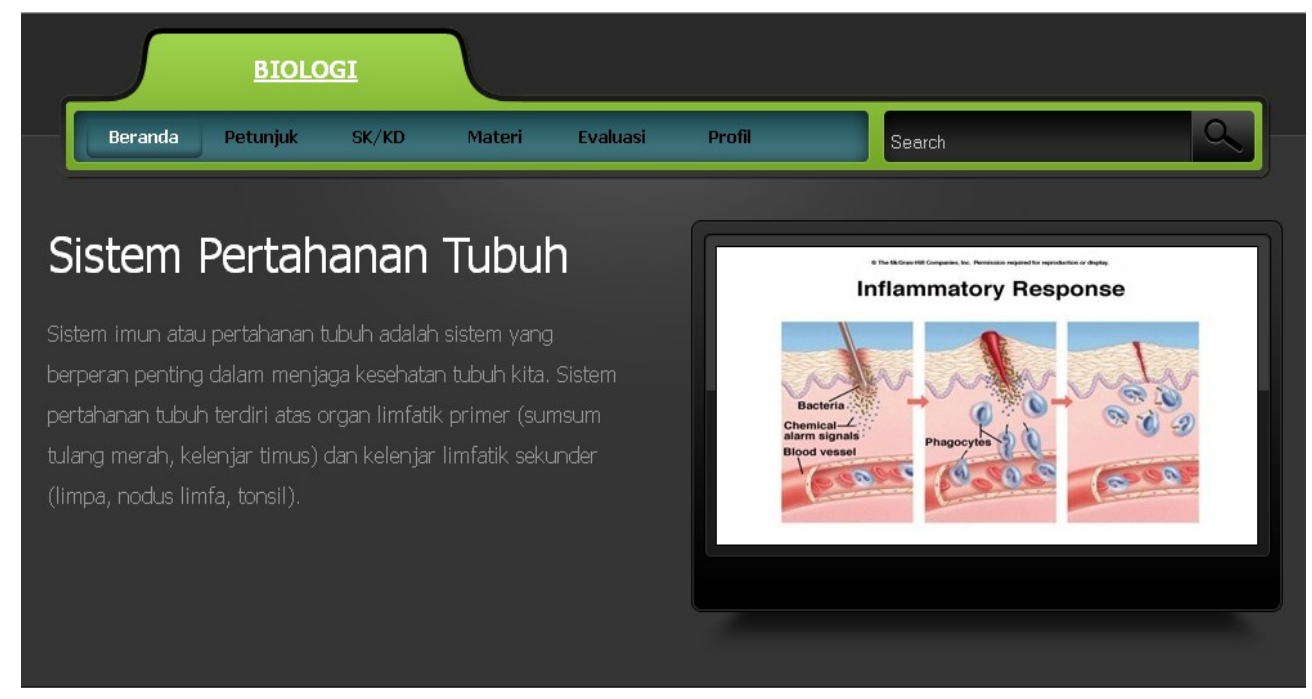

Gambar 1. Tampilan Utama

http://ojs.stkippgri-lubuklinggau.ac.id/index.php/JPP 
Halaman utama berisi beberapa tombol yang berfungsi untuk mengakses halaman yang diinginkan. Tombol-tombol yang berada di halaman utama tersebut antara lain tombol Beranda, Petunjuk, SK/KD, Materi, Evaluasi, dan Profil.

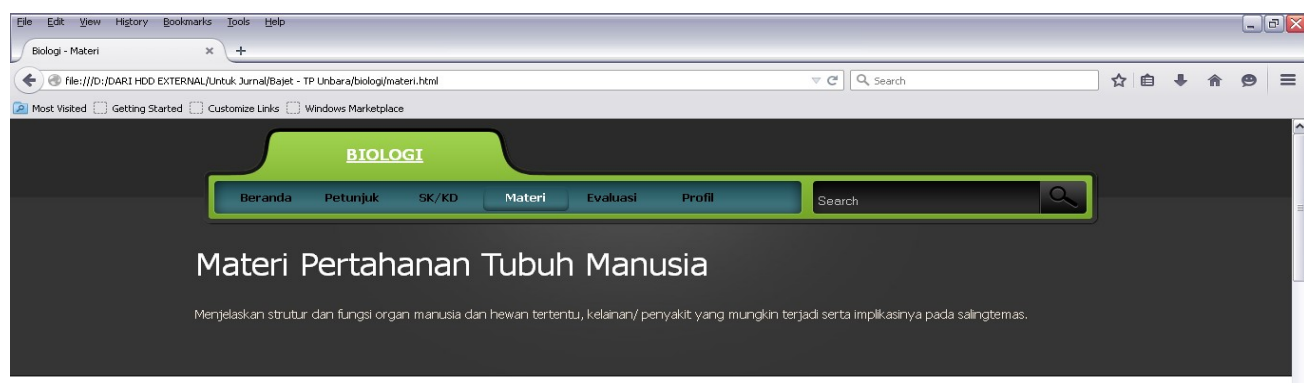

Pertahanan tubuh manusia

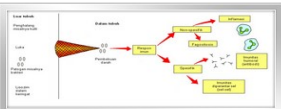

Sistem imun atau pertahsnar tubuh adalah sistem yang berperan penting dalam menjaga kesehatan tubuh

Tahapan aktivitas sel pertahanan tubuh dalam menghadapi zat asing

\section{Gambar 2. Tampilan Utama Materi}

Halaman materi ini merupakan sub menu dari halaman utama. Pada halaman ini terdapat tombol selengkapnya untuk menghubungkan ke materimateri selengkapnya. Jika menu selengkapnya di klik, maka akan ditampilkan halaman materi secara lengkap untuk memudahkan pengguna dalam mengakses materi pelajaran. Tampilannya sebagai berikut.

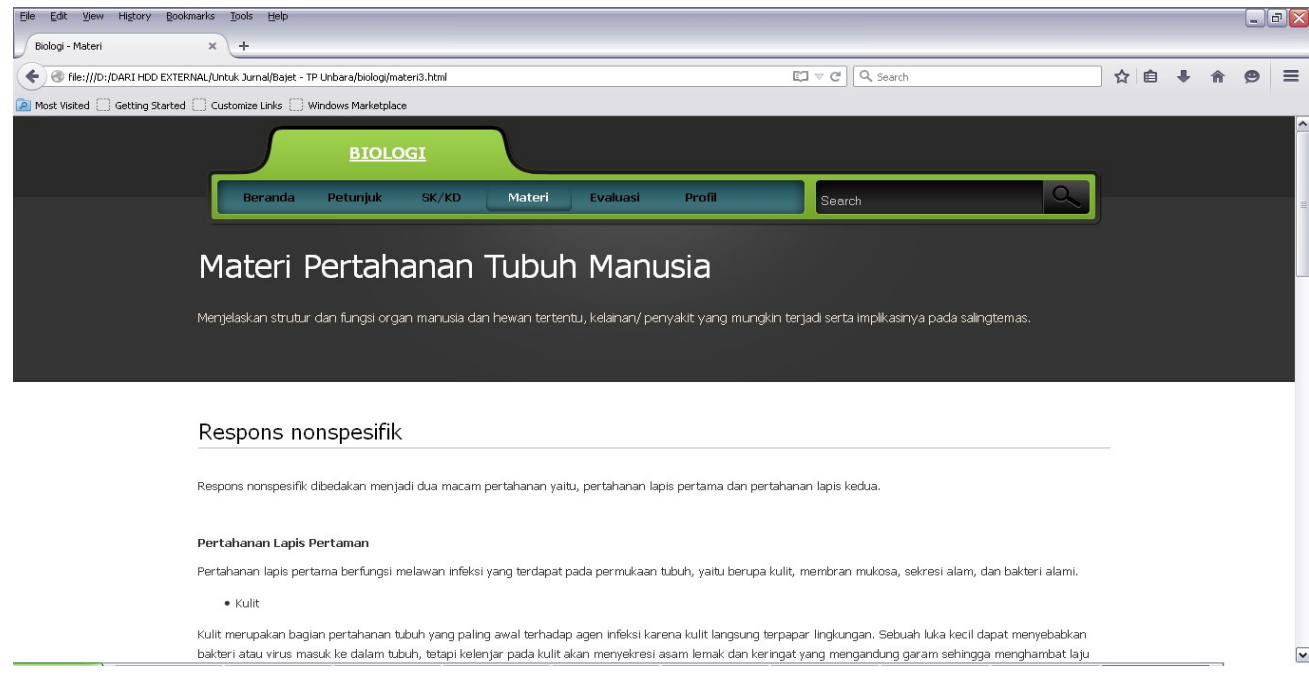

Gambar 3. Tampilan Halaman Materi

http://ojs.stkippgri-lubuklinggau.ac.id/index.php/JPP 
Halaman evaluasi berisi soal-soal yang digunakan untuk mengukur kemampuan siswa melalui produk media pembelajaran berbasis web. Sebelum masuk ke pilihan evaluasi pengguna harus mengisi identitas nama dan kelas terlebih dahulu, kemudian klik tombol mulai untuk masuk ke pilihan evaluasi.

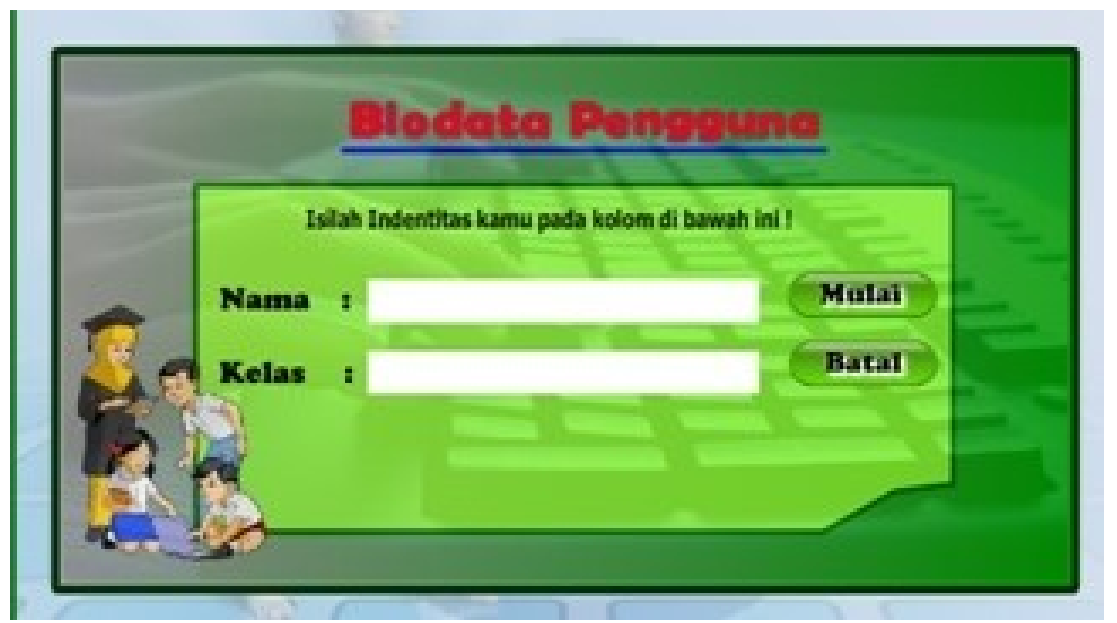

Gambar 4. Tampilan Login Evaluasi

Setelah siswa mengisi kolom identitas, lalu program akan memunculkan soal evaluasi dari no 1 . Perolehan skor atas pengerjaan soal evaluasi akan terlihat setelah soal terakhir selesai dijawab.

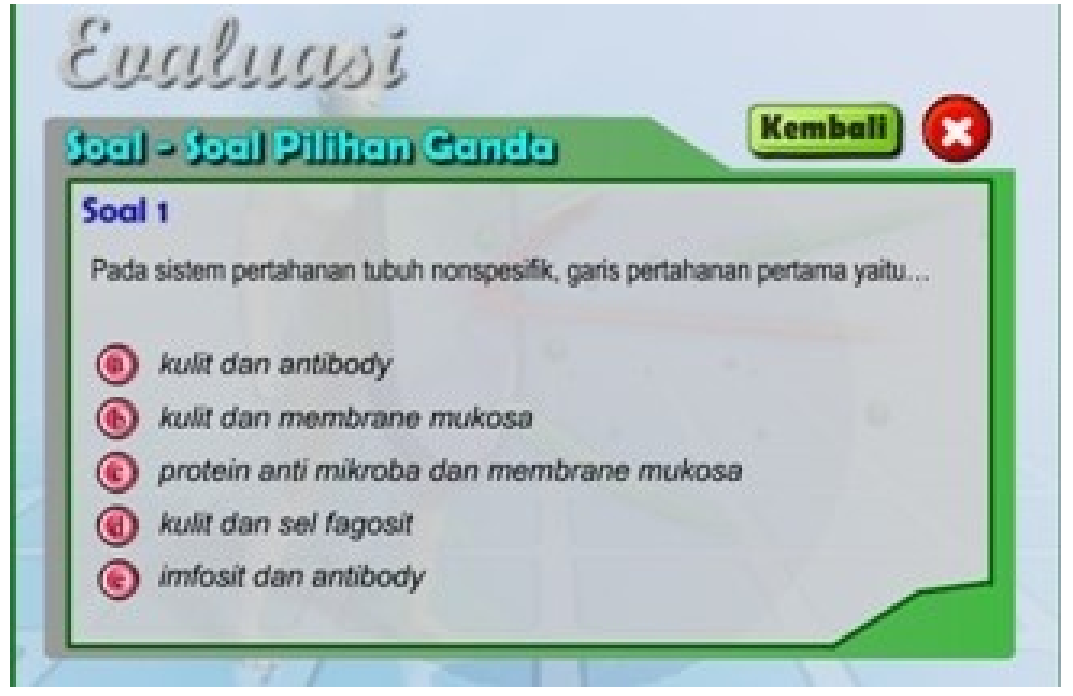

Gambar 5. Tampilan Evaluasi

http://ojs.stkippgri-lubuklinggau.ac.id/index.php/JPP 


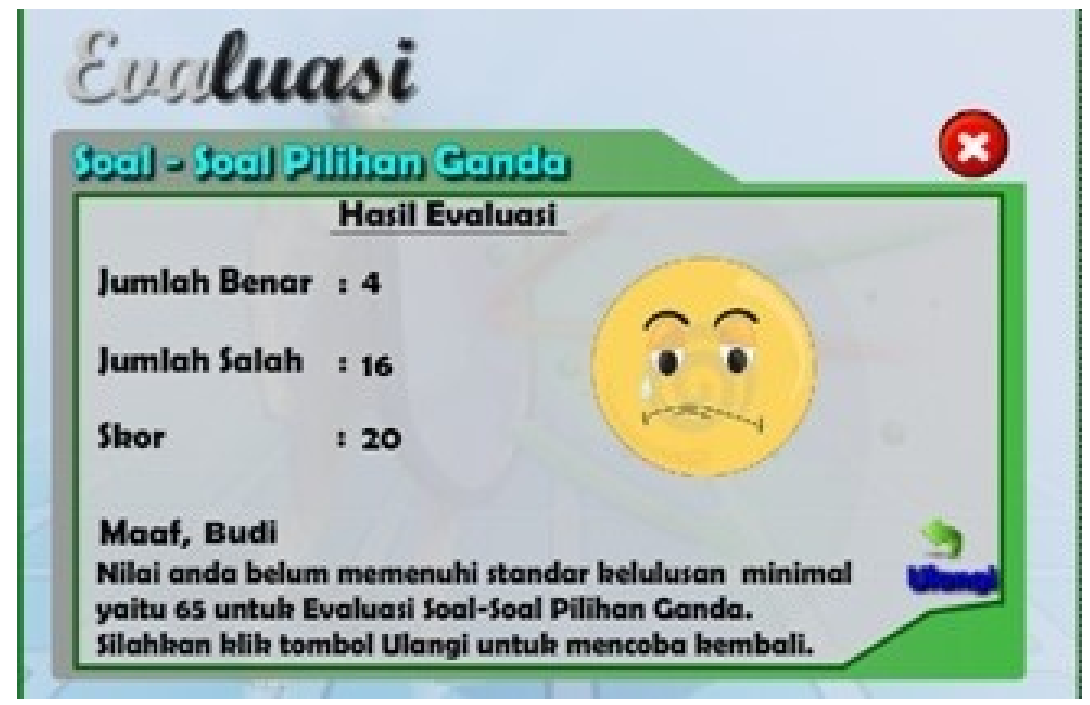

\section{Gambar 6. Tampilan Hasil Evaluasi}

Halaman hasil evaluasi akan ditampilkan setelah soal telah selesai dijawab/dikerjakan. Perolehan skor atas pengerjaan soal evaluasi akan terlihat setelah soal terakhir selesai dijawab.

\section{Pembahasan}

Media pembelajaran berbasis ini dibuat sesuai dengan standar kompetensi dan kompetensi dasar pada mata pelajaran Biologi Kelas X. Media pembelajaran ini sudah melalui tahap validasi oleh ahli, yaitu ahli media, ahli desain, dan ahli materi sebelum akhirnya dilakukan uji coba kelapangan yaitu uji coba perorangan, uji coba skala kecil dan uji coba skala besar. Data hasil uji coba produk media pembelajaran berbasis web ini adalah: a) hasil uji coba ahli media, diperoleh ratarata persentase secara keseluruhan dari angket pengujian sebesar 79\% dengan predikat baik, b) hasil uji coba ahli desain, diperoleh rata-rata persentase secara keseluruhan dari angket pengujian sebesar 78\% dengan predikat baik, c) hasil uji coba ahli materi, diperoleh rata-rata persentase secara keseluruhan dari angket pengujian sebesar $80 \%$ dengan predikat baik, d) hasil uji coba skala perorangan, diperoleh rata-rata persentase secara keseluruhan dari angket pengujian sebesar $82 \%$ dengan predikat baik, e) hasil uji coba skala kecil, diperoleh rata-rata 
persentase secara keseluruhan dari angket pengujian sebesar $81 \%$ dengan predikat baik, f) hasil uji coba skala besar, diperoleh rata-rata persentase secara keseluruhan dari angket pengujian sebesar $82 \%$ dengan predikat baik. Berdasarkan data hasil uji coba yang diperoleh maka pengembangan media pembelajaran berbasis web pada mata pelajaran Biologi kelas X dapat dikatakan layak untuk diterapkan di sekolah.

Secara umum media pembelajaran berbasis web ini memiliki beberapa kelebihan yaitu menarik dan menyenangkan karena disajikan dengan menyesuaikan karakteristik siswa. Mulai dari penggunaan warna tampilan, gambar, efek animasi sederhana, dan efek sound, sehingga tidak membosankan pengguna dalam menggunakan media. Media pembelajaran berbasis web ini mudah digunakan oleh pengguna dengan perintah-perintah yang bersifat sederhana, dan pengguna secara aktif dapat memilih menu yang diinginkan. Soalsoal yang terdapat dalam media pembelajaran berbasis web ini di tampilkan secara acak sehingga dapat meminimalkan kemungkinan siswa untuk menghafal jawaban.

Selain mempunyai beberapa kelebihan, media pembelajaran berbasis web ini juga memiliki kekurangan atau kelemahan, yaitu produk media pembelajaran berbasis web hanya ditujukan untuk siswa kelas $\mathrm{X}$ semester satu sehingga ketika siswa memasuki semester dua harus dibuat kembali produk media pembelajaran berbasis web yang baru.

\section{KESIMPULAN}

Produk yang dihasilkan adalah media pembelajaran berbasis web pada mata pelajaran biologi kelas X. Keseluruhan produk media pembelajaran berbasis web terdiri dari teks, gambar, animasi, suara, dan video sehingga sangat menarik dan interaktif untuk digunakan sebagai media pembelajaran di sekolah. Media pembelajaran berbasis web ini sebelumnya telah melakukan tahap evaluasi oleh para ahli, yaitu ahli media, ahli desain, dan ahli materi yang memperoleh kriteria kelayakan "baik". Kemudian uji coba yang dilakukan pada siswa dengan skala perorangan memperoleh kriteria kelayakan "baik", uji coba skala kecil http://ojs.stkippgri-lubuklinggau.ac.id/index.php/JPP 
memperoleh kriteria kelayakan "baik", dan uji coba skala besar memperoleh kriteria kelayakan "baik". Jadi dapat disimpulkan bahwa media pembelajaran berbasis web ini memiliki tingkat kelayakan dan kemenarikan produk pada kriteria baik, hal ini dibuktikan dengan hasil pengumpulan data melalui angket terdapat rata-rata persentase butir intstrumen dalam kriteria baik. Berdasarkan data hasil yang diperoleh maka pengembangan media pembelajaran berbasis web pada mata pelajaran biologi kelas X dapat dikatakan layak untuk diterapkan di sekolah.

\section{DAFTAR PUSTAKA}

Borg, W. R. \& Gall, M. D. (2003). Educational research: an introduction (7th ed.). New York: Longman, Inc.

Heru Supriyono, Sujalwo, Adjie Sapoetra, Endah Tri Rahayu. (2015). Pelatihan Pengembangan Media Pembelajaran Berbasis Web Bagi guru SMP dan SMA Muhammadiyah Kartasura. WARTA, Vol .18, No.2, September 2015: 98 - 109.

Putra, Nusa. (2011). Research \& Development Penelitian dan Pengembangan: Suatu Pengantar. Jakarta: Rajawali Pers.

Rusman. 2013. Belajar dan Pembelajaran Berbasis Komputer. Bandung: Alfabeta.

Tim EMS. 2014. Teoridan Praktik PHP-MySQL untuk Pemula. Jakarta: PT Elex Media Komputindo.

Warsita, Bambang, 2008. Teknologi Pembelajaran Landasan Dan Aplikasinya. Jakarta: Rineka Cipta. 